\title{
Temperature stability of ZnO:Al film properties for poly-Si thin-film devices
}

K. Y. Lee, C. Becker, M. Muske, F. Ruske, S. Gall, B. Rech, M. Berginski, and J. Hüpkes

Citation: Appl. Phys. Lett. 91, 241911 (2007);

View online: https://doi.org/10.1063/1.2824456

View Table of Contents: http://aip.scitation.org/toc/apl/91/24

Published by the American Institute of Physics

\section{Articles you may be interested in}

Improved electrical transport in Al-doped zinc oxide by thermal treatment

Journal of Applied Physics 107, 013708 (2010); 10.1063/1.3269721

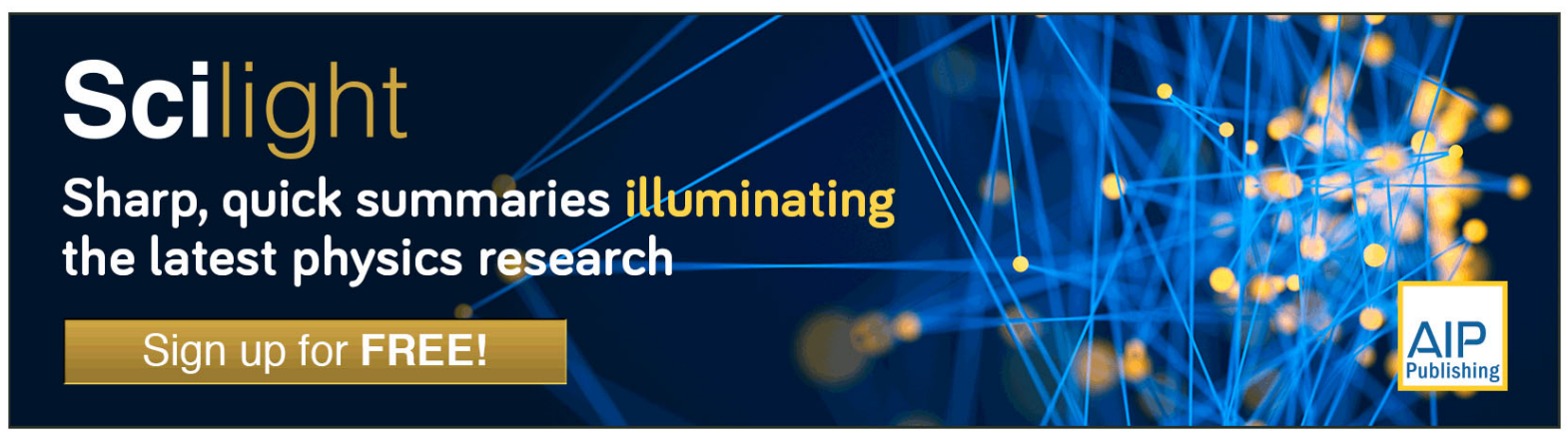




\title{
Temperature stability of ZnO:Al film properties for poly-Si thin-film devices
}

\author{
K. Y. Lee, ${ }^{\text {a) }}$ C. Becker, M. Muske, F. Ruske, S. Gall, and B. Rech \\ Hahn-Meitner-Institut Berlin GmbH, Kekuléstr. 5, D-12489 Berlin, Germany \\ M. Berginski and J. Hüpkes \\ Institute of Energy Research-Photovoltaics (IEF-5), Forschungszentrum Jülich GmbH, \\ D-52425 Jülich, Germany
}

(Received 30 August 2007; accepted 23 November 2007; published online 14 December 2007)

\begin{abstract}
The crystallization of thin silicon films at temperatures between 425 and $600{ }^{\circ} \mathrm{C}$ was investigated on glass substrates coated with Al-doped zinc oxide ( $\mathrm{ZnO}: \mathrm{Al}$ ). Bare $\mathrm{ZnO}$ :Al layers degrade at the crystallization temperatures used. A silicon layer on top, however, efficiently prevents deterioration. The resistivity was even found to drop from $4.3 \times 10^{-4} \Omega \mathrm{cm}$ for the as deposited $\mathrm{ZnO}$ :Al to 2.2 $\times 10^{-4} \Omega \mathrm{cm}$ in the case of aluminium induced crystallization and to $3.4 \times 10^{-4} \Omega \mathrm{cm}$ for solid phase crystallization. The temperature-stable conductivity of $\mathrm{ZnO}$ :Al films coated with Si opens up appealing options for the production of polycrystalline silicon thin-film solar cells with transparent front contacts. (C) 2007 American Institute of Physics. [DOI: 10.1063/1.2824456]
\end{abstract}

Thin polycrystalline silicon (poly-Si) films on foreign substrates (e.g., glass) feature the potential to combine the advantages of both crystalline silicon wafers (high material quality) and thin-film technologies (low costs). This is especially interesting for the preparation of low-cost, high efficiency thin-film solar cells. Thin poly-Si films on glass for solar cells can be prepared for example by (i) solid phase crystallization (SPC), ${ }^{1,2}$ where amorphous $\mathrm{Si}(a-\mathrm{Si})$ is transformed to poly-Si by annealing at about $600{ }^{\circ} \mathrm{C}$, or (ii) the "seed layer approach,"3 where in a first step a very thin largegrained poly-Si film (seed layer) is formed and in a second step this seed layer is thickened homoepitaxially at about $600{ }^{\circ} \mathrm{C}$. An attractive method to prepare such large-grained seed layers is the aluminum-induced layer exchange (ALILE). ${ }^{4-7}$ The ALILE process is a special form of aluminum-induced crystallization. A substrate/Al/ $a$-Si stack is transformed into a substrate/poly-Si/ $\mathrm{Al}(+\mathrm{Si})$ stack by a simple annealing step below the eutectic temperature of the $\mathrm{Al} / \mathrm{Si}$ system $\left(577^{\circ} \mathrm{C}\right)$.

In both cases SPC and ALILE, an annealing step is necessary so that only temperature-stable substrates can be used. The formation of poly-Si films on transparent conductive oxides (TCOs), however, would be an appealing option, especially for the preparation of thin-film solar cells in superstrate configuration because they allow for a simple contacting scheme and light trapping. ${ }^{8,9}$ In the case of cells based on $a-\mathrm{Si}: \mathrm{H}$ or $c-\mathrm{Si}: \mathrm{H}, \mathrm{ZnO}: \mathrm{Al}$ is a promising TCO material due to its high stability in hydrogen-rich plasmas. ${ }^{10}$

Studies on the stability of $\mathrm{ZnO}: \mathrm{Al}$ upon treatment at higher temperatures as used for the crystallization of Si have so far concentrated on annealing of thin films on glass under various conditions. Usually a strong decrease of electrical conductivity is observed during annealing in air at temperatures above $300-400{ }^{\circ} \mathrm{C},{ }^{11,12}$ while much higher temperatures can be applied in vacuum ${ }^{13}$ or, in the case of rapid thermal annealing, nitrogen. ${ }^{14}$ As the films do not show structural degradation but rather an improved crystallinity, Minami et al. suggested oxygen to be responsible for both the decreased carrier density and mobility upon annealing in air. ${ }^{15}$ Only recently the formation of poly-Si layers on

\footnotetext{
${ }^{a)}$ Electronic mail: kyuyoul.lee@hmi.de
}

$\mathrm{ZnO}: \mathrm{Al}$ coated glass using the ALILE process has been introduced, ${ }^{16,17}$ but no comments on the evolution of $\mathrm{ZnO}$ properties were given.

In this paper, we show that $\mathrm{ZnO}: \mathrm{Al}$ is temperature stable when capped with $\mathrm{Si}$ and, thus, suitable for the preparation of poly-Si thin-film solar cells. For this, we investigated two types of glass/ZnO:Al/poly-Si samples. The poly-Si was formed by either (i) the ALILE process or (ii) the SPC process.

The $\mathrm{ZnO}$ :Al films were deposited on the cleaned glass substrates in an in-line system in dynamic mode using nonreactive rf sputtering from ceramic targets containing 1 wt. $\% \mathrm{Al}_{2} \mathrm{O}_{3}$ at a substrate temperature of $300{ }^{\circ} \mathrm{C}$. ${ }^{18}$ The thickness of the $\mathrm{ZnO}: \mathrm{Al}$ films, determined by fitting optical transmission and reflection spectra, was between 690 and $770 \mathrm{~nm}$. These kinds of films are usually applied for the development of state-of-the-art amorphous and microcrystalline Si based single and multijunction solar cells. ${ }^{9}$

The layers for the ALILE process ( $\mathrm{Al}$ and $a$-Si) were deposited onto the $\mathrm{ZnO}: \mathrm{Al}$ coated glass by dc magnetron sputtering in argon atmosphere at room temperature. The thicknesses of the Al layer and the $a$-Si layer were 300 and $375 \mathrm{~nm}$, respectively. The initial glass/ZnO: $\mathrm{Al} / \mathrm{Al} / a-\mathrm{Si}$ stacks were annealed in a tube furnace at an annealing temperature $T_{A}$ between 425 and $525{ }^{\circ} \mathrm{C}$ in $\mathrm{N}_{2}$ ambient. The samples annealed at 425 and $450{ }^{\circ} \mathrm{C}$ were annealed for $16 \mathrm{~h}$ and the samples annealed between 475 and $525^{\circ} \mathrm{C}$ were annealed for $4 \mathrm{~h}$. Finally, the resulting top layer ( $\mathrm{Al}$ and $\mathrm{Si}$ islands) was removed by chemical mechanical polishing (CMP). Therefore, the resulting structure is glass/ZnO:Al/ poly-Si with an average silicon grain size of $5 \mu \mathrm{m} .{ }^{17}$

For the SPC-based experiments, intrinsic $a$-Si layers were deposited on $\mathrm{ZnO}$ :Al coated glass by e-beam evaporation at room temperature. The thickness of the $a$-Si layer was about $290 \mathrm{~nm}$. The initial glass/ZnO:Al/a-Si stacks were annealed in a tube furnace at $600{ }^{\circ} \mathrm{C}$ for $24 \mathrm{~h}$ in $\mathrm{N}_{2}$ atmosphere. During annealing the initially amorphous silicon was crystallized and glass/ZnO:Al/poly-Si stacks were formed.

For comparison all the different annealing steps were also applied to (i) glass/ZnO:Al samples, (ii) glass/Al/a-Si samples (ALILE process without $\mathrm{ZnO}: \mathrm{Al}$ ), and (iii) glass/ $a$-Si samples (SPC process without $\mathrm{ZnO}: \mathrm{Al})$. The electrical properties were studied by four-point probe and Hall mea- 


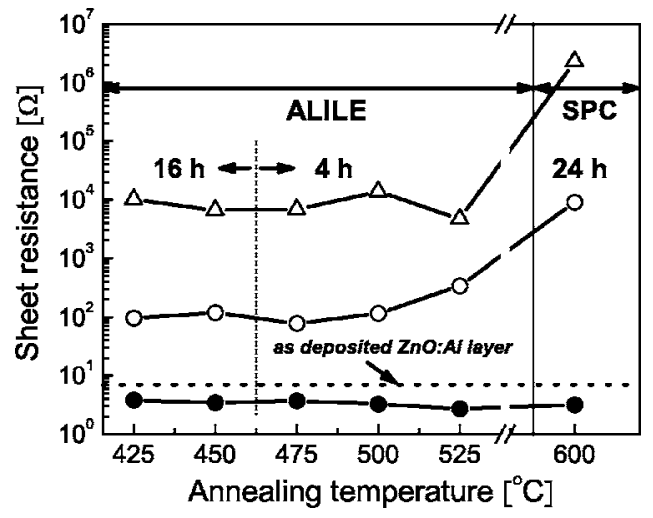

FIG. 1. The sheet resistance $\left(R_{s}\right)$ of glass/ZnO:Al/poly-Si $(\bullet)$, glass/ZnO:Al $(\bigcirc)$ and glass/poly-Si $(\triangle)$ stacks as a function of the annealing temperature. For reference, $R_{\text {sh }}$ of the glass/ZnO:Al layers before annealing is indicated with a dashed line. The poly-Si films were formed by either ALILE or SPC.

surements in van der Pauw geometry. The optical properties were investigated by measuring transmission and reflection spectra. In order to study the influence of the annealing temperature the electrical and optical properties were measured before and after annealing.

Figure 1 shows the sheet resistance $\left(R_{\mathrm{sh}}\right)$ of the different samples as a function of the annealing temperature: glass/ $\mathrm{ZnO}: \mathrm{Al}$ (open circles), glass/poly-Si (open triangles), and glass/ZnO:Al/poly-Si (solid circles). For comparison, the sheet resistance of as deposited $\mathrm{ZnO}$ : Al layers $(6.3 \Omega / \mathrm{sq})$ is indicated with a dashed line.

The sheet resistance of the annealed glass/ZnO:Al samples (open circles) is significantly increased compared to the as deposited value despite the nitrogen ambient, in which $\mathrm{ZnO}: \mathrm{Al}$ is known to more stable as compared to air or oxygen atmosphere. ${ }^{19}$ In contrast, the sheet resistances of the glass/ZnO:Al/poly-Si samples (solid circles) are even lower than the sheet resistance of as deposited $\mathrm{ZnO}$ :Al layer. This is an effect of improved $\mathrm{ZnO}: \mathrm{Al}$ quality as the silicon does not contribute to the total resistance of the stack considerably. The resulting sheet resistance of the glass/ZnO:Al/ poly-Si samples is almost independent of the annealing temperature (around $3 \Omega / \mathrm{sq}$ ). Hence, the Si layer on top of the $\mathrm{ZnO}$ :Al effectively prevents the degradation by oxygen or nitrogen. In contrast, the heat treatment even improves the zinc oxide properties and the resistivity for the sample annealed at $425^{\circ} \mathrm{C}$ drops from approx. $(4.3 \pm 0.1) \times 10^{-4}$ to only $(2.2 \pm 0.1) \times 10^{-4} \Omega \mathrm{cm}$.

For the SPC at $600{ }^{\circ} \mathrm{C}$ for $24 \mathrm{~h}$ the difference between the sheet resistance of the glass/ZnO:Al sample (open circle) and the glass/ZnO:Al/poly-Si sample (solid circle) is more than three orders of magnitude. Again the resistivity of the $\mathrm{ZnO}: \mathrm{Al}$ films was improved, in this case to a value of $(3.4 \pm 0.1) \times 10^{-4} \Omega \mathrm{cm}$. This is a very promising result regarding the application of sputtered $\mathrm{ZnO}: \mathrm{Al}$ layers in poly-Si thin-film solar cells.

In addition to the electrical properties, the influence of the annealing on the optical properties was also studied. Figure 2 shows the absorption spectra of three different samples before and after annealing at $600{ }^{\circ} \mathrm{C}$ for $24 \mathrm{~h}$ (SPC experiments): (i) glass/ZnO:Al before annealing (dashed line), (ii) glass/ZnO:Al after annealing (solid line), and (iii) glass/ $\mathrm{ZnO}: \mathrm{Al} /$ poly-Si after annealing (solid circles). It can be clearly seen that the heat treatment of the glass/ZnO:Al

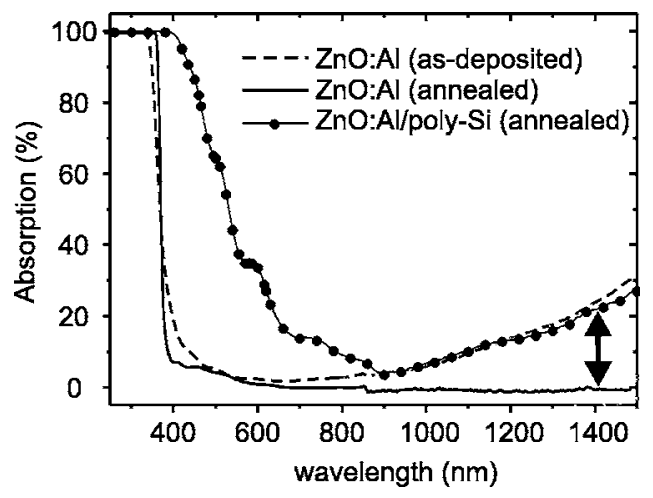

FIG. 2. Absorption spectra of $\mathrm{ZnO}: \mathrm{Al}$ films on glass before (dashed line) and after (solid line) annealing, as well as of a glass/ZnO:Al/poly-Si stack after annealing (solid circles). Annealing was performed at $600{ }^{\circ} \mathrm{C}$ for $24 \mathrm{~h}$ in $\mathrm{N}_{2}$ ambient (SPC experiments). The arrow indicates the remaining free carrier absorption of the glass/ZnO:Al/poly-Si stack after annealing.

samples leads to a disappearance of free carrier absorption in the Near-Infrared (NIR). The disappearance of free carriers can explain the strong increase of sheet resistance seen in Fig. 1. For the glass/ZnO:Al/poly-Si stack, however, the free carrier absorption in the NIR is preserved (indicated with an arrow) although the stack has been annealed for the same time. Bare poly-Si films have no absorption in this spectral region.

For a better understanding of the change of electrical properties during crystallization, Hall measurements were carried out on three samples, namely the as deposited $\mathrm{ZnO}: \mathrm{Al}$ film, the glass/ZnO:Al/poly-Si stack formed by ALILE and CMP for annealing at $425^{\circ} \mathrm{C}$, and the glass/ $\mathrm{ZnO}: \mathrm{Al} /$ poly-Si stack formed by SPC. It should be noted that in all cases the Si layer does not contribute to the electrical transport noticeably, so the measured values could be solely attributed to the $\mathrm{ZnO}: \mathrm{Al}$ layer. The results are summarized in Table I.

While the improved conductivity of the ALILE sample is mostly due to higher carrier concentration $N_{e}$ in the $\mathrm{ZnO}: \mathrm{Al}$ film, no change in carrier concentration can be observed for the SPC. Instead the mobility $\mu$ increases strongly. The measured value of $52.6 \mathrm{~cm}^{2} / \mathrm{V} \mathrm{s}$ is close to the theoretical limit proposed by Ellmer, ${ }^{20}$ and thus higher than the experimental limit found on the sputtering coater used in this study. ${ }^{18}$ This indicates two different processes are responsible for the increase of conductivity. The higher mobility for the SPC sample is most likely caused by an improved crystallinity of the $\mathrm{ZnO}: \mathrm{Al}$ film after the annealing. The increased electron concentration of the ALILE sample probably results from a diffusion of $\mathrm{Al}$ into the $\mathrm{ZnO}$ :Al film during the annealing and, thus, is a peculiarity of the ALILE process. The effect of the improved crystallinity of the $\mathrm{ZnO}$ :Al film expected after

TABLE I. Resistivity $\rho$, carrier concentration $N_{e}$, and hall mobility $\mu$ of the as deposited $\mathrm{ZnO}: \mathrm{Al}$ film and $\mathrm{ZnO}: \mathrm{Al}$ films coated with poly-Si produced by the ALILE and the SPC process.

\begin{tabular}{ccccc}
\hline \hline Sample & $\begin{array}{c}\text { Crystallization } \\
\text { conditions }\end{array}$ & $\begin{array}{c}\rho \\
\left(10^{-4} \Omega \mathrm{cm}\right)\end{array}$ & $\begin{array}{c}N_{e} \\
\left(10^{20} \mathrm{~cm}^{-3}\right)\end{array}$ & $\begin{array}{c}\mu \\
\left(\mathrm{cm}^{2} / \mathrm{V} \mathrm{s}\right)\end{array}$ \\
\hline $\mathrm{ZnO}$ as dep. & - & $4.3 \pm 0.1$ & $3.5 \pm 0.1$ & $42.0 \pm 0.1$ \\
SPC & $24 \mathrm{~h}$ at $600^{\circ} \mathrm{C}$ & $3.4 \pm 0.1$ & $3.5 \pm 0.1$ & $52.6 \pm 0.1$ \\
ALILE & $16 \mathrm{~h}$ at $425^{\circ} \mathrm{C}$ & $2.2 \pm 0.1$ & $6.8 \pm 0.2$ & $41.8 \pm 0.2$ \\
\hline \hline
\end{tabular}


the annealing on mobility is probably compensated by increased ionized impurity scattering.

In conclusion, it was shown that crystallization of $a-\mathrm{Si}$ layers can also be carried out on $\mathrm{ZnO}$ :Al coated glass substrates using both ALILE and SPC. While uncoated $\mathrm{ZnO}: \mathrm{Al}$ films show a strong increase of resistivity upon heat treatment, $\mathrm{Si}$ coating of the $\mathrm{ZnO}$ :Al layers used in this study resulted in electrical properties that were not only stable but considerably improved. While for SPC this is a consequence of a higher mobility, a strong increase of carrier density was observed during the ALILE process. The temperature-stable conductivity of glass/ZnO:Al/Si layer stacks opens up appealing options for poly-Si thin-film devices including TCOs, e.g., solar cells. The transfer of the processes to textured $\mathrm{ZnO}: \mathrm{Al}$ films, as used for light trapping in solar cells based on $a-\mathrm{Si}: \mathrm{H}$ or $\mu c-\mathrm{Si}: \mathrm{H}$, is currently being investigated.

The work has been supported by the FP6 research project ATHLET (Contract No. 019670-FP6-IST-IP) and BMU project (Contract No. 0327581).

${ }^{1}$ T. Matsuyama, K. Wakisaka, M. Kameda, M. Tanaka, T. Matsuoka, S. Tsuda, S. Nakano, Y. Kishi, and Y. Kuwano, Jpn. J. Appl. Phys., Part 1 29, 2327 (1990).

${ }^{2}$ M. A. Green, P. A. Basore, N. Chang, D. Clugston, R. Egan, R. Evans, D. Hogg, S. Jarnason, M. Keevers, P. Lasswell, J. O'Sullivan, U. Schubert, A. Turner, S. R. Wenham, and T. Young, Sol. Energy 77, 857 (2004). ${ }^{3}$ W. Fuhs, S. Gall, B. Rau, M. Schmidt, and J. Schneider, Sol. Energy 77, 961 (2004)
${ }^{4}$ O. Nast, T. Puzzer, L. M. Koschier, A. B. Sproul, and S. R. Wenham, Appl. Phys. Lett. 73, 3214 (1998).

${ }^{5}$ O. Nast and A. J. Hartmann, J. Appl. Phys. 88, 124 (2000).

${ }^{6}$ O. Nast and S. R. Wenham, J. Appl. Phys. 88, 716 (2000).

${ }^{7}$ J. Schneider, J. Klein, M. Muske, S. Gall, and W. Fuhs, Appl. Phys. Lett. 87, 031905 (2005).

${ }^{8}$ J. Müller, B. Rech, J. Springer, and M. Vanecek, Sol. Energy 77, 917 (2004).

${ }^{9}$ B. Rech, T. Repmann, M. N. van den Donker, M. Berginski, T. Kilper, J. Hüpkes, S. Calnan, H. Stiebig, and S. Wieder, Thin Solid Films 511/512, 548 (2006).

${ }^{10}$ T. Minami, H. Sato, H. Nanto, and S. Takata, Thin Solid Films 176, 277 (1989).

${ }^{11}$ T. Minami, K. Oohashi, S. Takata, T. Mouri, and N. Ogawa, Thin Solid Films 193/194, 721 (1990).

${ }^{12}$ J. F. Chang, W. C. Lin, and M. H. Hon, Appl. Surf. Sci. 183, 18 (2001).

${ }^{13}$ Y. Igasaki, M. Ishikawa, and G. Shimaoka, Appl. Surf. Sci. 33/34, 926 (1988).

${ }^{14}$ K.-K. Kim, S. Niki, J.-Y. Oh, J.-O. Song, T.-Y. Seong, S.-J. Park, S. Fujita, and S.-W. Kim, J. Appl. Phys. 97, 066103 (2005).

${ }^{15}$ T. Minami, T. Miyata, and T. Yamamoto, J. Vac. Sci. Technol. A 17, 1822 (1999).

${ }^{16}$ D. Dimova-Malinovska, O. Angelov, M. Kamenova, A. Vaseashta, and J. C. Pivin, Dr. Dobb's J. 9, 355 (2007).

${ }^{17}$ K. Y. Lee, M. Muske, I. Gordon, M. Berginski, J. D’Haen, J. Hüpkes, S. Gall, and B. Rech, "Large-grained poly-Si films on $\mathrm{ZnO}$ :Al coated glass substrates," Thin Solid Films (submitted).

${ }^{18}$ C. Agashe, O. Kluth, J. Hüpkes, U. Zastrow, B. Rech, and M. Wuttig, J. Appl. Phys. 95, 1911 (2004).

${ }^{19}$ O. Hamad, G. Braunstein, H. Patil, and N. Dhere, Thin Solid Films 489, 303 (2005).

${ }^{20}$ K. Ellmer, J. Phys. D 34, 3097 (2001). 